\title{
Crop size influences pre-dispersal seed predation in the Brazilian Cerrado
}

\author{
Alexander V. Christianini ${ }^{1}$
}

Received: August 21, 2017

Accepted: October 2, 2017

\begin{abstract}
Many pre-dispersal seed predators are specialized insects that rely on seeds for larval development. These insects may respond to the amount of seeds produced by a plant (i.e. crop size), increasing the proportion of seeds damaged with increases in seed numbers. Large seeds have more resources and spend more time in plants to complete their development and are probably more prone to be preyed on by those insects than small seeds. Here I tested how crop size and seed mass influence pre-dispersal seed predation in plants from the Cerrado savannas of Brazil. I related plant crop size to pre-dispersal seed predation for Xylopia aromatica and Erythroxylum pelleterianum. A literature review was performed to test if seed mass may explain among-species differences in pre-dispersal seed predation. Pre-dispersal losses increased proportionally to crop size in the two species investigated, but some species show positive or no density-dependent seed predation in literature, indicating that seed losses are not a simple function of crop sizes. Seed mass did not explain pre-dispersal seed loss differences among 14 species with data available. Pre-dispersal losses are often small and probably less important than seed dispersal and establishment limitation for plant recruitment in Cerrado savannas.
\end{abstract}

Keywords: Brazil, crop size, Erythroxylum pelleterianum, savanna, seed number, seed predation, seed size, seed survival, Xylopia aromatica

\section{Introduction}

Seed crop size is the number of seeds produced by an individual plant in a given fruiting season. Crop size may vary in response to several factors. For instance, plants growing in more fertile soils tend to produce larger crops than those growing in nutrient-poor soils, as well as plants in larger growth forms (e.g. trees compared to shrubs and herbs) (Bogdziewicz et al. 2017; and references therein). Individual plant energy reserves, fluctuations in environmental conditions and outcross pollen limitation may produce temporal variations in seed crops (Kon et al. 2005). Plants producing smaller seeds also tend to have larger individual seed crops than plants with comparatively larger seeds (Moles \& Westoby 2006).

Plants producing more seeds may increase the likelihood of individual seed dispersal and recruitment, because they produce more attractive displays that increase the visits of vertebrate frugivores (Howe \& Estabrook 1977). However, some animals attracted to fruiting plants can behave as antagonists, such as granivores. Seeds are often a source of food for many animals, including vertebrates and invertebrates that may prey on the seeds and may thus decrease plant fitness (Hulme \& Benkman 2002; Kolb et al. 2007). Granivores can eat seeds after or before dispersal acting as post- and pre-dispersal seed predators, respectively. Vertebrates usually have a more prominent

1 Departamento de Ciências Ambientais, Universidade Federal de São Carlos Campus Sorocaba, 18052-780, Sorocaba, SP, Brazil. avchristianini@yahoo.com.br 
role as post-dispersal seed predators (but see Francisco et al. 2008), while invertebrates are more important in predispersal phase, where seeds are still attached to the plant (Janzen 1971; Hulme \& Benkman 2002; Kolb et al. 2007). It is common that herbivores feeding on flowers and fruits before dispersal severely decrease seed availability (Kolb et al. 2007; Christianini et al. 2013), and it is likely that plants producing larger seed crops may also be more attractive to specialized pre-dispersal seed predators (Howe \& Estabrook 1977; Kolb et al. 2007).

Many invertebrate seed predators (e.g. insects among Coleoptera, Diptera, Hymenoptera and Lepidoptera) rely on seeds as a substrate for their larval development and these interactions can be quite specialized (Janzen 1969; 1971; 1980; Kolb et al. 2007). Adult insects oviposit on developing fruits and seeds, and the larvae consume the seed tissue killing the embryo. Seeds are thus critical resources for pre-dispersal seed predator insects. Since larger seeds take longer to complete their development than small seeds, larger seeds offer better and prolonged opportunities to seed predators (Moles \& Westoby 2003). As seed predators may severely decrease the availability of seeds for recruitment, they could be a powerful ecological and evolutionary force shaping several plant traits, including crop size of plants (Hulme \& Benkman 2002; Kon et al. 2005; Kolb et al. 2007). Certain plants may produce great amounts of seeds, thus generating a very high but ephemeral concentration of resources in time and space that may satiate seed predators and increase the likelihood of individual seed survival (Kelly \& Sork 2002; Kon et al. 2005). In this case the amount of seed losses would stop to increase after crop size surpasses a value that saturates the possibility of oviposition and larval growth of insects (predator satiation hypothesis).

In the tropical savannas of Central South America, the Cerrados, regeneration by seed is critical to allow plant colonization of new sites distant from mother plants (e.g. Christianini \& Oliveira 2010). However, the low availability of nutrients in soil probably constrains seed production, what decreases seed availability for dispersal and plant regeneration (Salazar et al. 2012). Due to low nutrient availability increase in crop size is an unlikely plant strategy to satiate predators and decrease seed losses. However, studies about the impact of crop size on pre-dispersal seed predation are unusual in Cerrado (e.g. Francisco et al. 2008) and there is so far no synthesis about pre-dispersal seed predation in this savanna. Here I tested if pre-dispersal seed predation is tied to plant crop sizes in the Brazilian Cerrado using original data from individual plant production in two species and tested if seed mass could be used as a predictor of seed losses based on a synthesis from the literature.

\section{Materials and methods}

Original data about the influence of crop size in the amount of pre-dispersal seed predation was obtained from plants growing in the Cerrado from Estação Experimental de Itirapina, a ca. 150 ha state park in Itirapina, Southeast Brazil ( $22^{\circ} 12^{\prime} \mathrm{S} 47^{\circ} 51^{\prime} \mathrm{W}$ ). The local vegetation is comprised by a Cerrado, the savanna like vegetation that grows on sandy, nutrient-poor soils of Central South America (Oliveira-Filho \& Ratter 2002). Annual mean rainfall and temperature is $1,360 \mathrm{~mm}$ and $21.8^{\circ} \mathrm{C}$ respectively, with occasional frost occurring in winter. The local tree and shrub flora is composed by around 100 species with Fabaceae, Myrtaceae and Melastomataceae among the most abundant local plants (Giannotti \& Leitão Filho 1992). The park is surrounded by Pinus L. and Eucalyptus L'Hér. plantations, as well as firebreaks and pasturelands, and is not subjected to fire since ca. 30 years (see Christianini \& Oliveira 2013).

Two species of plants common at the study site were used for the tests: the tree Xylopia aromatica (Lam.) Mart. (Annonaceae) and the shrub Erythroxylum pelleterianum A. St.-Hil. (Erythroxylaceae) (hereafter refereed by genus only). Both species produce diaspores primarily dispersed by birds and reproduce only by seed. Xylopia is pollinated by thrips and beetles (Gottsberger 1999), while flowers of Erythroxylum are visited by a diverse guild of small insects including bees, wasps and flies (AV Christianini unpubl. res.). Xylopia fruits from March to July, and produces dehiscent multiple fruits (divided in follicles) that open to expose ca. 60 seeds in total per fruit (see figure of fruit and a more detailed description in Christianini \& Oliveira 2010). Erythroxylum fruits from October to December, and produces single-seeded fruits (drupes) with great variation in fruiting among years (AV Christianini unpubl. res.). Both species have their seeds preyed before dispersal by Hymenoptera larvae that develop inside seeds, leaving a small hole after emergence of the adult (Christianini \& Oliveira 2010; AV Christianini \& PS Oliveira unpubl. res.).

Crop size was estimated on nine individuals of Xylopia (seven in 2004 reported in Christianini \& Oliveira 2010, plus other two sampled in 2005) and 10 of Erythroxylum (in 2004) haphazardly sampled in a 30 ha plot established at the study site. Plants sampled were never closer than $5 \mathrm{~m}$ from a reproductive conspecific. Crop sizes were obtained by direct counts on plant crown and also with the aid of seed traps (see detailed methods in Christianini \& Oliveira 2010). Briefly, from two to six $0.14 \mathrm{~m}^{2}$ seed traps were set at ground level beneath individual plant canopies. Seed trap contents were recorded fortnightly, and trap contents were carefully inspected and classified in an exclusive category as unripe (undeveloped fruit or seed), ripe (full seed in a ripe fruit), rotten (seed with signs of decay), or preyed on (with exit holes of pre-dispersal seed predators).

The influence of crop size on pre-dispersal predation was investigated with linear regressions. If pre-dispersal seed predators are not satiated, seed predation should increase isometricaly with crop size. Therefore, to test the influence of crop size on pre-dispersal seed predation first 
I fitted data obtained from Xylopia and Erythroxylum to a power-law function following Harms et al. (2000): $\log (y+1)$ $=a+b \log (x+1)$, where $x$ is the crop size per individual plant and $y$ is the number of seeds preyed upon; $b$ is the slope representing the variation in seed predation in relation to crop size and $a$ is the regression intercept. If $b=1$, seed predation is proportional to crop size (density independent). If $b>1$, the proportion of seeds preyed on increases with crop size (positive density-dependence). If $b<1$, the proportion of seeds preyed on decreases with increases in crop size (negative density-dependence; predator satiation). Deviations of the slopes from 1 were tested with the aid of a paired $t$-test comparing the observed number of surviving seeds and the expected if $b=1$ (Harms et al. 2000). Expected values were calculated by substituting $b$ for 1 in regression equations. All tests followed Zar (1999).

To investigate the influence of seed size on the amount of pre-dispersal seed predation at community level I also used linear regressions. First I obtained data from a synthesis of the literature about pre-dispersal seed predation in the Cerrado through a review of published articles. I searched the Web of Science (www.isiknowledge.com) and Scielo (www.scielo.br) platforms using "Cerrado AND seed AND predat* OR graniv"” in topic search in June 01, 2017. The results of the search were screened by title and abstracts. I also looked at the literature cited in the articles obtained by the search to increase literature cover. Articles were excluded if they did not quantify pre-dispersal seed predation or reported only post-dispersal data. If data were presented only in graphs I used ImajeJ (Rasband 1997) to calculate the original data using graph scales. When a species was studied in more than one site or year and data was presented separately, I consider each one as a study case. In these cases I included separate data for each site and year, respectively, otherwise means were used. This procedure allowed a better look at variation within and among species, but may provide pseudoreplication at species level. Therefore, the results should be interpreted with caution. Data on species seed mass were extracted from the original studies or obtained from the literature. This provided pre-dispersal seed predation and mass data for 28 cases involving 14 species distributed in 10 genera (Tab. 1).

Table 1. Summary of studies included in the review about pre-dispersal seed predation in Cerrado. Species are arranged in alphabetic order of family name. *Species that presented data for more than one site or year; †Values refer to range of seed predation for individual plants, mean per study site or years when applicable; \# Damaged fruits; $\ddagger$ Estimate of seed loss may be slightly inflated due to postdispersal seed predators; na = not available or evaluated in the study.

\begin{tabular}{|c|c|c|c|c|c|c|}
\hline Family & Species & Seed mass (g) & Main pre-dispersal seed predator & $\begin{array}{l}\text { Pre-dispersal } \\
\text { seed loss }(\%)^{+}\end{array}$ & $\begin{array}{c}\text { Relation of pre-dispersal } \\
\text { loss with crop size } \\
\text { (slope) }\end{array}$ & Reference \\
\hline \multirow[t]{2}{*}{ Annonaceae } & Annona crassiflora & 0.66 & Hymenoptera (Eurytomidae) & $53.8 \% \neq$ & na & Golin et al. 2011 \\
\hline & Xylopia aromatica & 0.06 & $\begin{array}{c}\text { Hymenoptera (Pteromalidae, } \\
\text { Eurytomidae) }\end{array}$ & $0.8 \%-10 \%$ & $\begin{array}{l}\text { Isometric with crop } \\
\text { size (1.132) }\end{array}$ & This study \\
\hline Caryocaraceae & Caryocar brasiliensis & 1.1 & Birds & $18 \%-43 \%$ & $\begin{array}{l}\text { Positive density } \\
\text { dependence (na) }\end{array}$ & Ragusa-Neto 2011 \\
\hline Erythroxylaceae & $\begin{array}{l}\text { Erythroxylum } \\
\text { pelleterianum }\end{array}$ & 0.041 & Hymenoptera & $0 \%-0.7 \%$ & $\begin{array}{l}\text { Isometric with crop } \\
\text { size }(0.6915)\end{array}$ & This study \\
\hline Fabaceae & Copaifera langsdorffii* & 0.476 & Coleoptera (Curculionidae) & $8.2 \%-15.9 \%$ & $\begin{array}{l}\text { No effect in one } \\
\text { study (na) }\end{array}$ & $\begin{array}{l}\text { Fagundes et al. 2013; } \\
\text { Souza \& Fagundes } 2017\end{array}$ \\
\hline Malvaceae & Eriotheca gracilipes & 0.3 & Birds & $0 \%-100 \%$ & $\begin{array}{c}\text { Positive density } \\
\text { dependence (1.21) }\end{array}$ & Francisco et al. 2008 \\
\hline \multirow[t]{4}{*}{ Mimosaceae } & Mimosa clausseni* & 0.113 & $\begin{array}{l}\text { Coleoptera (Curculionidae, } \\
\text { Bruchidae) and birds }\end{array}$ & $19.8 \%-56.5 \%$ & na & Simon \& Hay 2003 \\
\hline & M. decorticans & 0.388 & $\begin{array}{c}\text { Coleoptera (Curculionidae, } \\
\text { Bruchidae) }\end{array}$ & 6.1 & na & Simon \& Hay 2003 \\
\hline & M. heringeri & 0.347 & $\begin{array}{c}\text { Coleoptera (Curculionidae, } \\
\text { Bruchidae) }\end{array}$ & 9.2 & na & Simon \& Hay 2003 \\
\hline & M. setosissima & 0.317 & $\begin{array}{c}\text { Coleoptera (Curculionidae, } \\
\text { Bruchidae) }\end{array}$ & 2.3 & na & Simon \& Hay 2003 \\
\hline Solanaceae & Solanum lycocarpum & 0.038 & Rodents & $14 \%-75 \% \#$ & $\begin{array}{c}\text { Positive density } \\
\text { dependence (1.26) }\end{array}$ & $\begin{array}{l}\text { Briani \& Guimarães } \\
\text { Jr. } 2007\end{array}$ \\
\hline \multirow[t]{4}{*}{ Vochysiaceae } & Callisthene fasciculate* & 0.082 & No seed predator found & $0 \%$ & na & Custódio et al. 2014 \\
\hline & Callisthene major* & 0.588 & Coleoptera (Curculionidae) & $0 \%-51.34 \%$ & na & Custódio et al. 2014 \\
\hline & Qualea multiflora* & 0.0746 & $\begin{array}{l}\text { Coleoptera (Buprestidae) and } \\
\text { maybe Hymenoptera }\end{array}$ & $0 \%-43.97 \%$ & na & Custódio et al. 2014 \\
\hline & Qualea parviflora* & 0.033 & $\begin{array}{c}\text { Coleoptera (Buprestidae) and } \\
\text { maybe Hymenoptera }\end{array}$ & $20 \%-60.23 \%$ & na & Custódio et al. 2014 \\
\hline
\end{tabular}




\section{Results}

There was great variation in the crop sizes of individual plants. For Xylopia, crop sizes varied between 39 and 627, a 1,500\% difference (see also Christianini \& Oliveira 2010), while for Erythroxylum crop sizes varied between 252 and 4828, a 1,800 \% difference (AV Christianini \& PS Oliveira unpubl. res.). Damage from pre-dispersal seed predators was relatively low, from $0 \%$ to $13.7 \%$ of the seeds of Xylopia and Erythroxylum (Fig. 1). Pre-dispersal seed predation followed crop size variation in Xylopia $\left(\mathrm{r}^{2}=0.56\right.$ for a log-log linear regression: Pre-dispersal predation $=-1.646+1.132$ (Crop size); $\left.\mathrm{F}_{1,7}=9.08 ; \mathrm{p}=0.019\right)$, and the slope of the regression did not differ from 1 (paired $t$-test: $t=0.0005 ; \mathrm{df}=8 ; \mathrm{p}=0.99$ ) (Fig. 1). A qualitative similar result was obtained with the inclusion of data only for 2004 (seven trees) in the analysis (results not shown). The relation between crop size and predispersal seed predation in Erythroxylum followed the same trend $\left(r^{2}=0.54\right.$ : Pre-dispersal predation $=-1.7148+0.6915$ (Crop size); $\mathrm{F}_{1.8}=9.66 ; \mathrm{p}=0.014$ ), and the regression slope also did not differ from $1(t=0.002 ; \mathrm{df}=9 ; \mathrm{p}=0.998)$ (Fig. 1 ). Thus, for both species there was an isometric increase in seed predation with increase in crop size.

The literature review indicated great among-species variation in the amount of seed predation, from $0 \%$ in Callisthene fasciculate (Custódio et al. 2014) up to $100 \%$ in Eriotheca grassilipes (Francisco et al. 2008) (Tab. 1). There was also substantial within-species variation among years (e.g. $8.2 \%$ and $15.9 \%$ of seed predation in two years for Copaifera langsdorffii) (Souza \& Fagundes 2017) and sites (0\% and 51.3\% seed predation in two different sites for Callisthene major) (Custódio et al. 2014) (Tab. 1). Pre-dispersal seed predation was performed by birds or rodents in four species ( $27 \%$ ) while insects (Coleoptera and Hymenoptera) preyed on seeds of $10(67 \%)$ plants. One species (Callisthene fasciculate) had no seed predation recorded (Tab. 1 ). These large variations in pre-dispersal seed predation were not influenced by seed size $\left(\mathrm{F}_{1,26}=0.239 ; \mathrm{r}^{2}=0.01 ; \mathrm{p}=0.634\right)$ (Fig. 2$)$.

\section{Discussion}

There is a diversity of responses of pre-dispersal seed predators to crop size variation in Cerrado. While predispersal losses are proportional to crop size in Xylopia and Erythroxylum, for three other species (Caryocar brasiliensis, Eriotheca gracilipes and Solanum lycocarpum) the proportion of pre-dispersal losses increases with crop sizes indicating that seed predators are positively influenced by seed density (Tab. 1). For another species (Copaifera langsdorffii) increments in crop sizes between years were not followed by changes in seed losses, suggesting predator satiation (Souza \& Fagundes 2017). Enhancement of seeds losses with increasing seed density may constrain the evolution of large crop sizes. Indeed, Xylopia and Erythroxylum produce much larger annual crops than those plants affected by positive
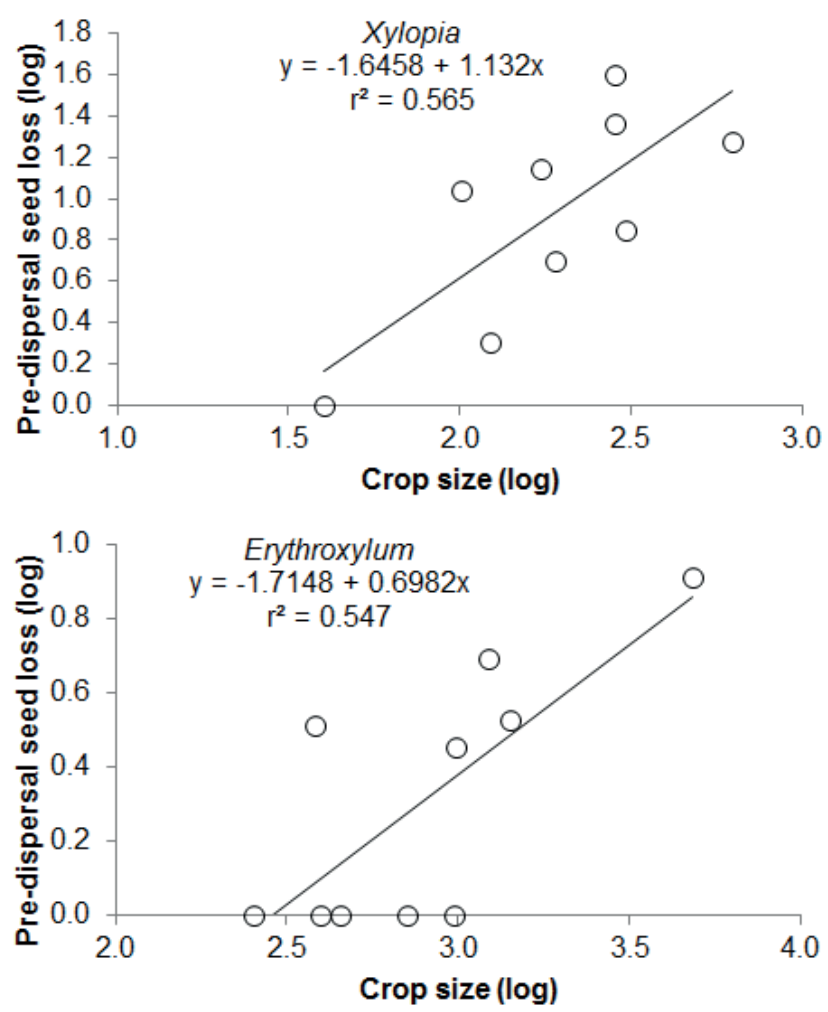

Figure 1. Relationships between individual plant crop sizes and the amount of pre-dispersal seed predation observed for plants of Xylopia aromatica (above) and Erythroyxlum pelleterianum (below) in a Cerrado from southeastern Brazil. Seed predation was influenced by crop size variation for both species but regression slopes did not differ from 1 .

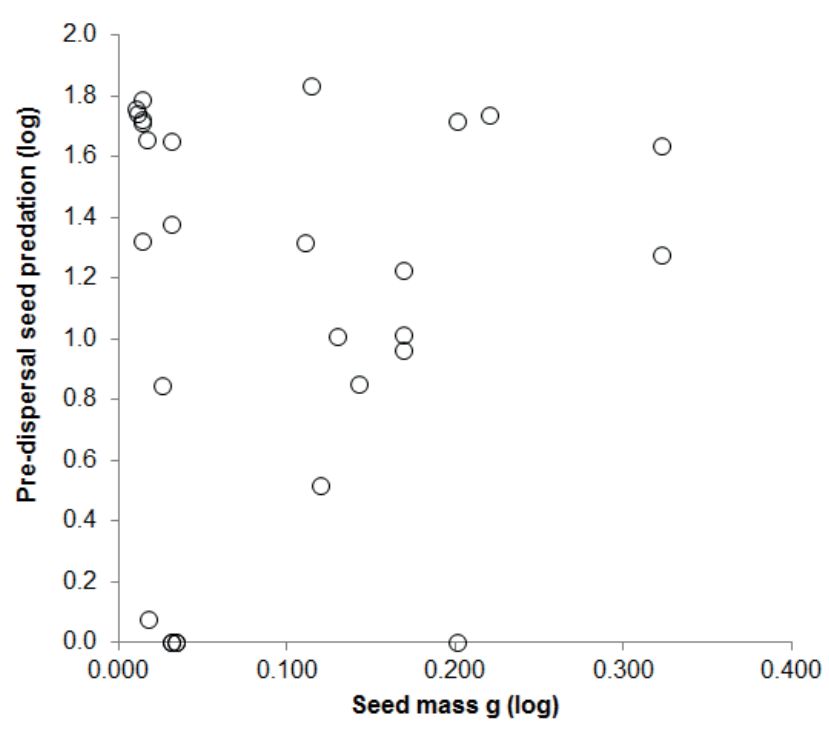

Figure 2. No effect of seed mass variation on the amount of predispersal seed predation recorded in studies with plants from the Cerrado. Data was obtained from 28 study cases with 14 species found in a literature search (see details in Materials and methods). 
density-dependence seed predation, although other traits such as growth form and seed mass may also be under these differences (see Moles \& Westoby 2006). Variable relationships between crop size and the likelihood of predispersal seed predation are also reported in other systems (Augspurger 1981; Jordano 1987; Brody \& Mitchell 1997; Kelly \& Sork 2002; Bogdziewicz et al. 2017), including great among and within species variation in pre-dispersal seed predation for other tropical savannas (Ernst et al. 1990; Custódio et al. 2014).

What are the consequences of the amount of seed losses for the plants? Unless the regeneration of plants are seed limited (Ferreira et al. 2011; Salazar et al. 2012), pre-dispersal seed predators are unlikely to decrease substantially plant fitness by reducing the amount of seeds available for recruitment. There is evidence that seed and dispersal limitation decrease the opportunities of recruitment of Xylopia and Erythroxylum to some extent (Christianini \& Oliveira 2010; 2013). However, the small amount of seeds lost to pre-dispersal predators does not seem to be enough to control the recruitment of these plants at the study site, with dispersal and establishment limitation playing a more important role (Christianini \& Oliveira 2010; 2013) as well as for other species in Cerrado (Ferreira et al. 2011; Salazar et al. 2012).

Data about the population abundance and fluctuation of the pre-dispersal seed predators are scarce, but the relative isolation and small size of the Cerrado fragment studied might be influencing the results. Pre-dispersal seed predation is often performed by specialized herbivores (Janzen 1969; 1971; 1980; Kolb et al. 2007). These herbivores often decrease in abundance and diversity following habitat fragmentation and declines in their host plants (RuizGuerra et al. 2010). However, Xylopia and Erythroxylum populations are among the most abundant plants at the study site (V Mariano \& AV Christianini unpubl. res.), and there is evidence that crop size of Erythroxylum is not influenced by edge effects (Christanini \& Oliveira 2013). Therefore, seed availability is probably not constraining the populations of the insect seed predators recorded. On the other hand, the high abundance of these plant species could indicate that predator satiation could be taking place at larger spatial scales beyond individual plants. Seed predators may respond to the density of seeds of several individual plants at close distance from each other, and to the costs and benefits of searching and moving among different plants or patches (Kelly \& Sork 2002; RagusaNetto 2011). Thus the satiation of seed predators could occur at patch rather than individual plant level (García \& Chacoff 2007). Unfortunately there is no data available to evaluate this hypothesis at the moment. Seed predation may also be subjected to temporal fluctuations that influence the satiation of predators (Kelly \& Sork 2002; Kon et al. 2005; Żywiec et al. 2013; Bogdziewicz et al. 2017). For instance, in tropical dry forests of Mexico, Erythroxylym havanense shows density-dependent seed predation in some years, while in other years seed predation fluctuate at random (Boege \& Domínguez 2008). There is also the possibility that plants aborted reproductive structures and the infested seeds before maturation due to herbivore attack (Christianini et al. 2013; Custódio et al. 2014), what may produce underestimates of seed losses measured latter during fruit maturation. Although I cannot eliminate this possibility, a visual inspection of aborted seeds sampled in traps showed no evidence of damage by seed predators, suggesting that Xylopia and Erythroxylum do not selectively aborted infested fruits (see also Boege \& Domínguez 2008 for Erythroxylum havanense).

Seed mass and investment in protective tissues are often correlated (Moles \& Westoby 2003; Ramírez \& Traveset 2010). Indeed, increases in seed mass and fiber, and a decrease in starch content decrease seed losses to pre-dispersal seed predators in savannas from Central Venezuela (Ramírez \& Traveset 2010). However, contrary to the expectation seed mass has no influence in pre-dispersal seed predation at community level in Cerrado. This result agrees with data compiled for several localities in Australia and around the world (Moles et al. 2003). If protective tissues alone drive pre-dispersal seed losses, larger seeds would suffer less predation in cerrado which is not the case. Specificity of seed predators, seed abundance, chemical traits and plant phenological patterns may also drive the interactions between a given seed predator and a plant (Janzen 1969; 1980; Kolb et al. 2007; Ramírez \& Traveset 2010). All those traits may influence the levels of seed predation detected, but currently there are no data available for Cerrado plant communities to evaluate their influences in detail. However, data from the current review suggest that pre-dispersal seed losses are correlated with crop sizes for most species that investigated this topic (five in six cases, Tab. 1), irrespective of seed size. For instance the crop size variation of the largest-seeded plant (Caryocar brasiliensis) and some of the smallest ones (Erythroxylum pelleterianum) in the sample produce similar responses of seed predators. Therefore, plant crop size seems to be a better predictor of seed losses than seed mass and it is possible that among year fluctuations in crop sizes may benefit plants from Cerrado. Populations of specialized seed predators may decline in years with no or low seed production, being more easily satiated in a subsequent year of high seed production as predicted by the predator satiation hypothesis in mast seeding species (Kelly \& Sork 2002; Kon et al. 2005). Future studies may evaluate this possibility.

In summary, individual plant crop size has variable but often a positive correlation with the amount of predispersal seed losses in the Cerrado, while among species seed mass differences is a poor predictor of pre-dispersal seed predation. Since crop size may be under negative selection by predators and positive selection by pollinators and seed dispersers (Howe \& Estabrook 1977; Kon et al. 2005; Boege \& Domínguez 2008; Bogdziewicz et al. 2017) it would be interesting to evaluate the net effect of crop size variation in 
plant recruitment in this savanna. At the same time, increase the knowledge about the biology of seed predators may allow us to test more refined hypothesis about the drivers of predispersal seed predation and how to conserve the tremendous diversity of interactions in this species rich savanna.

\section{Ackowledgements}

I thank Estação Ecológica e Experimental de Itirapina and Instituto Florestal de São Paulo for logistic support and licences. I also thank the Conselho Nacional de Desenvolvimento Científico e Tecnológico (CNPq: proc. 486113/2013-2) and Fundação de Amparo à Pesquisa do Estado de São Paulo (FAPESP: proc. 02/12895-8) for grants, and two anonymous referees for suggestions that improved the manuscript.

\section{References}

Augspurger CK. 1981. Reproductive synchrony of a tropical shrub: experimental studies on effects of pollinators and seed predators in Hybanthus prunifolius (Violaceae). Ecology 62: 775-778.

Boege K, Domínguez CA. 2008. Pre-dispersal seed predation reduces the compensatory advantage of thrum individuals in Erythroxylum havanense (Erythroxylaceae). Evolutionary Ecology 22: 675-687.

Bogdziewicz M, Crone EE, Steele MA, Zwolak R. 2017. Effect of nitrogen deposition on reproduction in a masting tree: benefits of higher seed production are trumped by negative biotic interactions. Journal of Ecology 105: 310-320.

Briani D, Guimarães Jr PR. 2007. Seed predation and fruit damage of Solanum lycocarpum (Solanaceae) by rodents in the cerrado of central Brazil. Acta Oecologica 31: 8-12.

Brody AK, Mitchell RJ. 1997. Effects of experimental manipulation of inflorescence size on pollination and pre-dispersal seed predation in the hummingbird-pollinated plant Ipomopsis aggregata. Oecologia 110: 86-93.

Christianini AV, Forzza RC, Buzato S. 2013. Divergence on floral traits and vertebrate pollinators of two endemic Encholirium bromeliads. Plant Biology 15: 360-368.

Christianini AV, Oliveira PS. 2010. Birds and ants provide complementary seed dispersal in a Neotropical savanna. Journal of Ecology 98: 573582.

Christianini AV, Oliveira PS. 2013. Edge effects decrease ant derived benefits to seedlings in a neotropical savanna. Arthropod-Plant Interactions 7: 191-199.

Custódio LN, Carmo-Oliveira R, Mendes-Rodrigues C, Oliveira PE. 2014. Pre-dispersal seed predation and abortion in species of Callisthene and Qualea (Vochysiaceae) in a Neotropical savanna. Acta Botanica Brasilica 28: 309-320.

Ernst WHO, Decelle JE, Tolsma DJ. 1990. Predispersal seed predation in native leguminous shrubs and trees in savannas in southern Botswana. African Journal of Ecology 28: 45-54.

Fagundes M, Maia MLB, Queiroz ACM, Fernandes GW, Costa FV. 2013. Seed predation of Copaifera langsdorffii Desf. (Fabaceae: Caesalpinoideae) by Rhinochenus brevicollis Chevrolat (Coleoptera: Curculionidae) in a Brazilian Cerrado fragment. Ecologia Austral 23: 218-221.

Ferreira AV, Bruna EM, Vasconcelos HL. 2011. Seed predators limit plant recruitment in Neotropical savannas. Oikos 120: 1013-1022.

Francisco MR, Lunardi VO, Guimarães PR, Galetti M. 2008. Factors affecting seed predation of Eriotheca gracilipes (Bombacaceae) by parakeets in a cerrado fragment. Acta Oecologica 33: 240-245.

García D, Chacoff NP. 2007. Scale-dependente effects of habitat fragmentation on Hawthorn pollination, frugivory and seed predation. Conservation Biology 21: 400-411.

Giannotti E, Leitão Filho HF. 1992. Composicão florística do cerrado da estacão experimental de Itirapina (SP). Anais do Congresso da Sociedade Botânica de São Paulo 8: 21-25.

Golin V, Santos-Filho M, Pereira MJB. 2011. Dispersão e predação de sementes de araticum no Cerrado de Mato Grosso, Brasil. Ciência Rural 41: 101-107.

Gottsberger G. 1999. Pollination and evolution in neotropical Annonaceae. Plant Species Biology 14: 143-152.

Harms KE, Wright SJ, Calderón O, Hernández A, Herre EA. 2000. Pervasive density-dependent recruitment enhances seedling diversity in a tropical forest. Nature 404: 493-495.

Howe HF, Estabrook GF. 1977. On intraspecific competition for avian dispersers in tropical trees. The American Naturalist 111: 817-832.

Hulme PE, Benkman CW. 2002. Granivory. In: Herrera CM, Pellmyr O. (eds.) Plant-animal interactions: An evolutionary approach. Oxford, Blackwell. p. 132-154.

Janzen DH. 1969. Seed-eaters versus seed size, number, toxicity and dispersal. Evolution 23: 19-27.

Janzen DH. 1971. Seed predation by animals. Annual Review of Ecology and Systematics 2: 465-492.

Janzen DH. 1980. Specificity of seed-attacking beetles in a Costa Rican deciduous forest. Journal of Ecology 68: 929-952.

Jordano P. 1987. Avian fruit removal: effects of fruit variation, crop size and insect damage. Ecology 68: 1711-1723.

Kelly D, Sork VL. 2002. Mast seeding in perennial plants: why, how, where? Annual Review of Ecology and Systematics 33: 427-447.

Kolb A, Ehrlén J, Eriksson O. 2007. Ecological and evolutionary consequences of spatial and temporal variation in pre-dispersal seed predation. Perspectives in Plant Ecology, Evolution and Systematics 9: 79-100.

Kon H, Noda T, Terazawa K, Koyama H, Yasaka M. 2005. Evolutionary advantages of mast seeding in Fagus crenata. Journal of Ecology 93: 1148-1155.

Moles AT, Warton DI, Westoby M. 2003. Do small-seeded species have higher survival through seed predation than larger seeds? Ecology 84: 3148-3161.

Moles AT, Westoby M. 2003. Latitude, seed predation and seed mass. Journal of Biogeography 30: 105-128.

Moles AT, Westoby M. 2006. Seed size and plant strategy across the whole life cycle. Oikos 113: 91-105.

Oliveira-Filho AT, Ratter JA. 2002. Vegetation physiognomies and woody flora of the cerrado biome. In: Oliveira PS, Marquis RJ. (eds.) The Cerrados of Brazil: Ecology and natural history of a Neotropical savanna. New York, Columbia University Press. p. 91-120.

Ragusa-Netto J. 2011. Pre-dispersal seed predation by Blue-and-yellow Macaw (Ara ararauna, Psittacidae) on fruit crops of the Pequi (Caryocar brasiliense, Caryocaraceae), in the Brazilian Cerrado. Ornitologia Neotropical 22: 329-338.

Ramírez N, Traveset A. 2010. Predispersal seed predation by insects in the Venezuelan Central Plain: Overall patterns and traits that influence its biology and taxonomic grops. Perspectives in Plant Ecology, Evolution and Systematics 12: 193-209.

Rasband WS. 1997. ImageJ. U. S. National Institutes of Health. Maryland, Bethesda Softworks. https://imagej.nih.gov/ij/ 10 Aug. 2017.

Ruiz-Guerra B, Guevara R, Mariano N, Dirzo R. 2010. Insect herbivory declines with forest fragmentation and covaries with plant regeneration mode: Evidence from a Mexican tropical rain forest. Oikos 119: 317325.

Salazar A, Goldstein G, Franco AC, Miralles-Wilhelm F. 2012. Seed limitation of woody plants in Neotropical savannas. Plant Ecology 213: 273-287.

Simon MF, Hay JDV. 2003. Comparison of a common and rare species of Mimosa (Mimosaceae) in Central Brazil. Austral Ecology 28: 315-326.

Souza ML, Fagundes M. 2017. Seed predation of Copaifera langsdorffii (Fabaceae): a tropical tree with supra-annual fruiting. Plant Species Biology 32: 66-73.

Zar JH. 1999. Biostatistical analysis. 2nd. edn. New York, Prentice-Hall.

Żywiec M, Holeksa J, Ledwoń M, Seget P. 2013. Reproductive success of individuals with different fruit production patterns. What does it mean for the predator satiation hypothesis? Oecologia 172: 461-467. 